\title{
Deoxyguanosine kinase mutation producing juvenile-onset mitochondrial myopathy
}

F.N.U. Komal, MD, Paolo M. Moretti, MD, and Aziz I. Shaibani, MD

Neurol Genet 2018;4:e269. doi:10.1212/NXG.0000000000000269
Correspondence

Dr. Komal

komalnaeem91@yahoo.com

Mitochondrial myopathies are associated with mutations of both mitochondrial and nuclear DNA. Deoxyguanosine kinase (DGUOK) is a nuclear gene responsible for maintaining the mitochondrial deoxynucleotide pool required for replication and maintenance of mitochondrial DNA (mtDNA). Homozygous or compound heterozygous DGUOK mutations are associated with decreased activity of the mtDNA-encoded respiratory chain complexes, mtDNA depletions ${ }^{1-4}$ and deletions. ${ }^{5}$ We describe a case of juvenile-onset mitochondrial myopathy associated with DGUOK-related multiple mtDNA deletions.

\section{Case report}

A 38-year-old woman presented with painless slowly progressive symmetrical proximal muscle weakness since she was 8 years old. On initial presentation, she reported difficulty climbing, holding her arms upright, running, and competing with her classmates. Her weakness was largely attributed to her being overweight. For 1 year before presentation, she had also developed diplopia in far vision. However, no primary eye disease was found. She denied shortness of breath, exercise-induced muscle cramps, hearing impairment, palpitations, seizures, and speech difficulty. Her medical history was significant for obsessive-compulsive disorder and Raynaud phenomena. Her family history included her mother and a brother with big calf muscles who were positive for proximal muscle weakness.

Her neurologic examination was notable for limited eye abduction bilaterally and mild right lid ptosis. Other cranial nerves were intact. She had mild calf hypertrophy and scapular winging. She had mild proximal muscle weakness graded on the Oxford scale as $4 / 5$ in deltoids, $4 / 5$ in supraspinatus muscles, $3 / 5$ in hip flexors, and $5 / 5$ elsewhere. Ankle reflexes were diminished with no gait abnormality. Cardiac and ear examinations were normal.

Her creatine kinase was elevated to $503 \mathrm{U} / \mathrm{L}$. MRI of the pelvis and thighs without contrast was performed, which showed symmetric fatty infiltration of pelvic and thigh muscles with reduced muscle bulk. EMG did not reveal a myogenic or neurogenic pattern. Biopsy of the left biceps was consistent with a mitochondrial myopathy, with many ragged red and blue fibers, moderate variation in fiber morphology, and many cytochrome oxidase-negative and succinate dehydrogenase-positive fibers (figure, A).

Next-generation sequencing and deletion/duplication analysis of 319 nuclear genes using the blood sample revealed 2 mutations in the DGUOK gene: c.195G $>\mathrm{A}$ and c.462T $>\mathrm{A}$ in exon 2 and 4, respectively. Parental data were not available to confirm cis or trans configuration. Mitochondrial genome sequencing and deletion analysis was performed using the muscle sample, which identified 3 large deletions of the mitochondrial genome: 10.7, 12.6, and $9.6 \mathrm{~kb}$. The sum total of heteroplasmy of these deletions was estimated to be less than 15 percent as it was confirmed by sequencing and not by array comparative genomic hybridization.

From the University of Texas Health Science Center (F.N.U.K.), Houston; University of Utah (P.M.M.); and Baylor College of Medicine (A.I.S.), Houston, TX.

Funding information and disclosures are provided at the end of the article. Full disclosure form information provided by the authors is available with the full text of this article at Neurology.org/NG.

The Article Processing Charge was funded by the authors.

This is an open access article distributed under the terms of the Creative Commons Attribution-NonCommercial-NoDerivatives License 4.0 (CC BY-NC-ND), which permits downloading and sharing the work provided it is properly cited. The work cannot be changed in any way or used commercially without permission from the journal. 
Figure COX:succinate dehydrogenase (SHD) stain and deoxyguanosine kinase (DGUOK) primary sequence

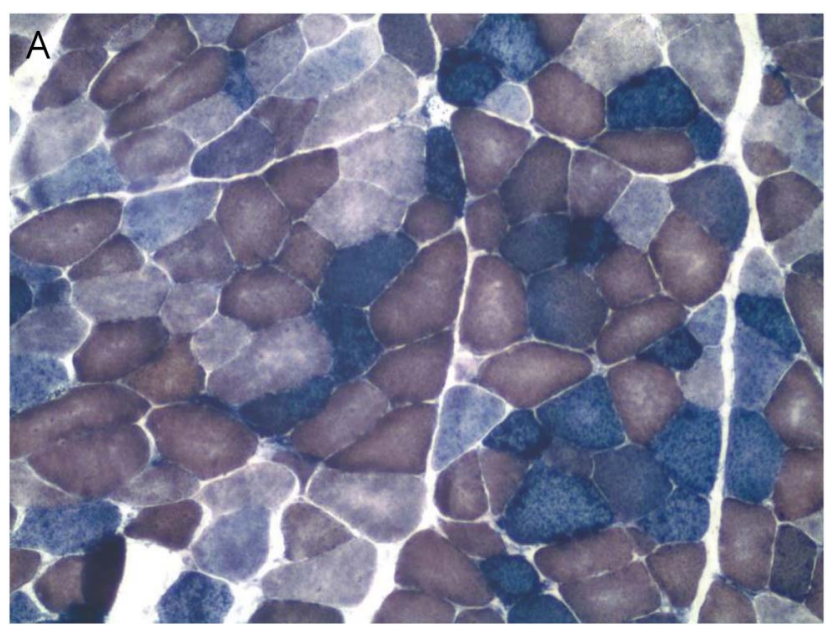

B

$\begin{array}{llllllllllllll}\text { Hs } & Y & \text { I } & F & A & K & N & L & E & F & E & N & G & 159 \\ \text { Mm } & Y & \text { I } & F & A & K & N & L & E & F & E & N & G & 159 \\ \text { Dr } & Y & \text { I } & F & A & L & N & M & A & F & A & L & G & 151 \\ \text { Dm } & Y & C & F & V & E & N & M & R & R & R & N & G & 122\end{array}$

(A) Muscle biopsy showing many cytochrome oxidase-negative/SHD-positive (blue stained) fibers ( $\times 100$ magnification). (B) Primary sequence of DGUOK showing the position of asparagine $(\mathrm{N})$ in different species including humans (Hs), mouse (Mm), zebrafish (Dr), and Drosophila (Dm).

The patient was diagnosed with DGUOK-related autosomal recessive multiple mitochondrial deletion syndrome, producing proximal muscle weakness and external ophthalmoparesis. She was counseled about exercise, dietary, and supportive measures.

\section{Discussion}

Mitochondrial myopathy is a disease of skeletal muscles, with or without CNS involvement, caused by defective mitochondrial metabolism. It is produced by defects in nuclear or mtDNA. Several nuclear genes are responsible for replication and maintenance of mtDNA including POLG, POLG2, C10ORF2, TYMP, TK2, RR2MB, and DGUOK. ${ }^{6}$ Defects in these genes affect mtDNA content (number of copies) or cause mtDNA deletions.

Loss-of-function mutations in DGUOK are associated with autosomal recessive inheritance of 3 main phenotypes: mtDNA depletion syndrome-3; noncirrhotic portal hypertension; and autosomal recessive progressive external ophthalmoplegia (PEO) with mtDNA deletions. Mutations in DGUOK have largely been described in mtDNA depletion syndromes, producing a multisystem illness or isolated liver disease. ${ }^{1,2,4}$ Myopathy has rarely been observed with early onset of symptoms. ${ }^{3}$ Moreover, compared with cases with decreased mtDNA content, only a few cases with mtDNA deletions producing myopathy have been reported. Six such cases were reported in 2012, in which age at onset of limb or extraocular weakness ranged from 20 to 69 years, and the majority (5) were older than 40 years. ${ }^{5}$ In contrast, our case presented with proximal muscle weakness at age 8 years and remained free of liver disease. Our participant harbors 2 mutations in the DGUOK gene, which have both been known to occur only in trans to other pathogenic variants, suggesting a trans configuration in our patient. The c.195G $>$ A mutation is predicted to produce a p.Trp65Ter nonsense pathogenic variant. It has a frequency of $8.12 \times 10^{-6}$ in a control population of normal individuals sequenced by next-generation sequencing (NGS). ${ }^{7}$ It has been reported with neonatal hepatocerebral disease in trans to another truncating mutation. . The second variant, c. $462 \mathrm{~T}>\mathrm{A}$, is predicted to result in the Asn154Lys substitution, with a significantly higher frequency of $1.34 \times 10^{-4}$ in normal controls. ${ }^{7}$ It has been reported in cases of adult-onset PEO in trans with other pathogenic variants. ${ }^{5}$ The asparagine at position 154 (figure, B) is highly conserved in evolution from Drosophila melanogaster to humans, suggesting an important role in maintaining protein structure or function.

Our case expands the phenotypic spectrum of DGUOK mutations and highlights the importance of NGS in children and adults to timely diagnose mitochondrial myopathy. The markedly slow progression of symptoms observed in our case may have contributed to the delay in diagnosis. Longitudinal studies are needed to further investigate the course and predict the outcomes in patients harboring DGUOK mutations.

\section{Author contributions}

F.N.U. Komal: drafting the manuscript. P.M. Moretti: critical revision of the manuscript for important intellectual content and preparation of the figure. A.I. Shaibani: acquisition of data and study supervision.

\section{Study funding}

This was not an industry-supported study. All authors have reported no financial conflicts of interest. There was no investigational or off-label use.

\section{Disclosure}

This was not an industry-supported study. All authors have reported no financial conflicts of interest. There was no investigational or off-label use. F.N.U. Komal reports no disclosures. P.M. Moretti has received research support from the NIH, the New Jersey Commission on Brain Injury Research, and the Department of Veterans Affairs. A.I. Shaibani receives publishing royalties from Oxford University Press. Full disclosure form information provided by the authors is available with the full text of this article at Neurology.org/NG.

Received February 26, 2018. Accepted in final form June 26, 2018. 


\section{References}

1. El-Hattab AW, Scaglia F. Mitochondrial DNA depletion syndromes: review and updates of genetic basis, manifestations, and therapeutic options. Neurotherapeutics 2013;10:186-198.

2. Freisinger P, Fütterer N, Lankes E, et al. Hepatocerebral mitochondrial DNA depletion syndrome caused by deoxyguanosine kinase (DGUOK) mutations. Arch Neurol 2006;63:1129-1134.

3. Buchaklian AH, Helbling D, Ware SM, Dimmock DP. Recessive deoxyguanosine kinase deficiency causes juvenile onset mitochondrial myopathy. Mol Genet Metab 2012;107:92-94.
4. Dimmock D, Zhang Q, Dionisi-Vici C, et al. Clinical and molecular features of mitochondrial DNA depletion due to mutations in deoxyguanosine kinase. Hum Mutat 2008;29:330-331.

5. Ronchi D, Garone C, Bordoni A, et al. Next-generation sequencing reveals DGUOK mutations in adult patients with mitochondrial DNA multiple deletions. Brain 2012; 135:3404-3415.

6. Copeland WC. Defects in mitochondrial DNA replication and human disease. Crit Rev Biochem Mol Biol 2012;47:64-74.

7. Lek M, Karczewski KJ, Minikel EV, et al. Analysis of protein-coding genetic variation in 60,706 humans. Nature 2016;536:285. 


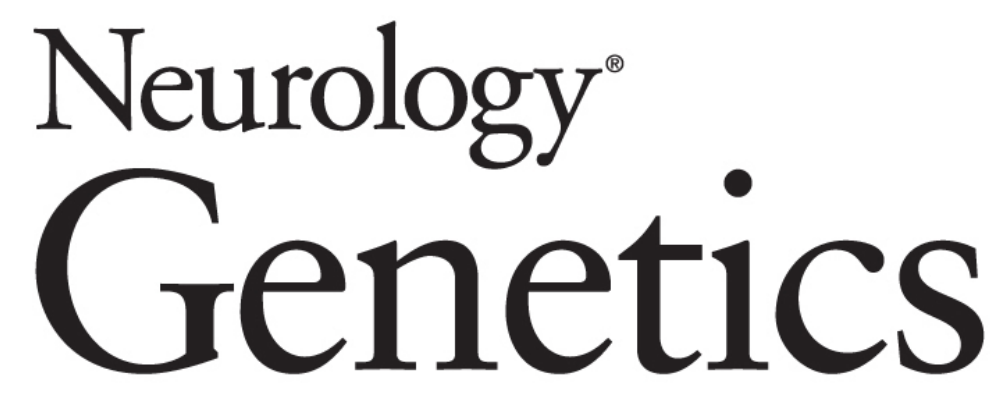

Deoxyguanosine kinase mutation producing juvenile-onset mitochondrial myopathy

F.N.U. Komal, Paolo M. Moretti and Aziz I. Shaibani

Neurol Genet 2018;4;

DOI 10.1212/NXG.0000000000000269

This information is current as of September 19, 2018

Updated Information \&

Services

References

Permissions \& Licensing

Reprints including high resolution figures, can be found at: http://ng.neurology.org/content/4/5/e269.full.html

This article cites 7 articles, 0 of which you can access for free at: http://ng.neurology.org/content/4/5/e269.full.html\#\#ref-list-1

Information about reproducing this article in parts (figures,tables) or in its entirety can be found online at:

http://ng.neurology.org/misc/about.xhtml\#permissions

Information about ordering reprints can be found online: http://ng.neurology.org/misc/addir.xhtml\#reprintsus

Neurol Genet is an official journal of the American Academy of Neurology. Published since April 2015, it is an open-access, online-only, continuous publication journal. Copyright Copyright ( 2018 The Author(s). Published by Wolters Kluwer Health, Inc. on behalf of the American Academy of Neurology.. All rights reserved. Online ISSN: 2376-7839.

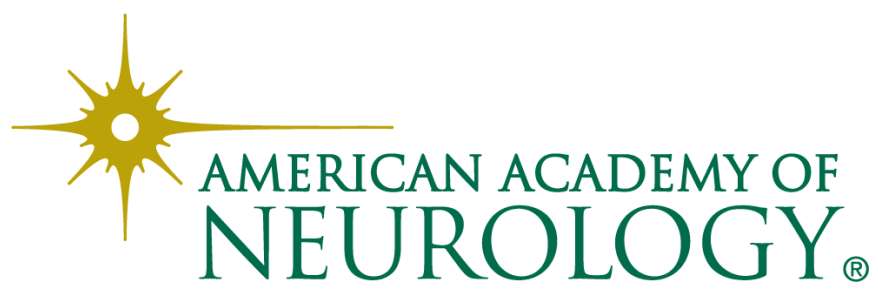

